FACTA UNIVERSITATIS

Series: Visual Arts and Music Vol. 5, No 1, 2019, pp. 11 - 29

https://doi.org/10.22190/FUVAM1901011M

Original scientific paper

\title{
THE FUNCTION OF HARMONY IN MUSICAL DRAMATURGY: SONGS OF HADŽI TOMA AND ALIL IN THE MUSIC DRAMA KOŠTANA BY PETAR KONJOVIC
}

UDC 782:781.4 KOŠTANA, P. KONJOVIĆ

\section{Marko S. Milenković}

University of Niš, Faculty of Arts, Niš, Serbia

\begin{abstract}
This paper explores and determines specific features of the harmonic language of Petar Konjovic (1883-1970) in relation to the music-dramatic portraits of Hadži Toma and Alil - the two main characters in the composer's most significant opera "Koštana" (1931), inspired by the playof Borisav Stankovic (1876-1927). Viewed through a starting hypothesis by which harmony is one of the most important elements of Konjovic's modernity, this paper primarily aims to precisely identify the harmonic potentials of the composer's ,speach“ in the songs of the afore mentioned protagonists. The very musicdramatic function of the chosen songs has been an inspiring subject of this research. Another, non the less atractive subject was enlightening Konjovic's relation towards folklore, with the special focus in his approach towards harmonizing folk songs. Special attention was payed to aspects of Konjovic's relation towards the heritage of Mokranjac. Results of the harmonic analysis have proven that the vertical dimension of the chosen songs show a skillful refraction of tonal and modal space with specific folklore scales and formulas which, along with the chordal diversity, points to an individual harmonic system and music thought of Petar Konjovic as an authentic representative of the „national orientation "in the developmental period of Serbian music between the two World wars, within its - at that time - Yugoslav and European frames.
\end{abstract}

Key words: Petar Konjovic, Koštana, dramaturugy, folklore, song, tonality, chord.

Received April 2019 / Accepted April 2019

Corresponding author: Marko S. Milenković

University of Niš, Faculty of Arts

E-mail: lionheartmarko@gmail.com 


\section{The Historical AND STYLISTIC CONTEXT OF THE Music Drama KOŠTANA}

Konjović completed the music drama Koštana at the beginning of the fourth decade of the $20^{\text {th }}$ century, precisely in $1931^{1}$, at the time when European art music in its evolution had already considerably encompassed and established a whole complex of the contemporary harmonic means and compositional techniques. It was a special historical moment, not only of European but also of Serbian art music, with series of contradictions and opposing stylistic tendencies. According to musicologist Katarina Tomašević, Serbian music of that era ${ }^{2}$, "stylistically polyvalent, weaved from several polyphonic generational and stylistic flows, exposed to the avant-garde impacts of young returnees from Prague and to returning to the tradition of ... [other] composers" (Tomašević 2003, 22) has achieved significant results in reaching the current European trends. In such complex historical conditions of the epoch, Konjovic choses tradition as the starting point for his own gradual stylistic path, striving for the modernization of the inherited framework of Mokranjac's era towards the mastering, and even expanding the expressive means of the late Romanticism with elements of impressionist and expressionist speech. Following Mokranjac as a directpredecessor and model in the aspect of harmony as well, the composer lightly but surely departed from Mokranjac'ssolutions, following the steps forward "to the new shores." In the case of Konjović, these "new shores" had the meaning of embracing the idea of the poetics of modernism. On the other hand, as a supporter of the idea of modernistic music realism in music drama, Konjović gradually built his stylistic path, finding the central starting point and role models in the "Slavic composers of the Eastern Orientation", about whom he wrote with piety (Konjović 1947, 117-125).

The relation of Petar Konjović towards folklore in the music drama Koštana has brought up questions and problems both regarding the individual composer's approachto the harmonization of folksongs, as well as integrating the music material of indisputable folkore origin into a primarily artistic narative of the piece. Analysis of compositional procedures with folklore material as one of the key determinants of Konjovic's poetics and style, induced considering a special function of the "folklore aspects of the opera" in the context of its overall music-dramatic flow. According to Biljana Bulović, "there is a big ... difference in the harmonic language of those fragments in the opera which are based on processed folklore quotations or original Konjović's melodies composed in a folklore manner, from those fragments which are not directly linked to folklore" (Bulović 1998, 150). The assumption of

\footnotetext{
${ }^{1}$ Version of the piano reduction score that I used was published by The National publishing house of Yugoslavia in 1946, while the orchestral score was published by the Association of Composers of Serbia in 1968.

${ }^{2}$ According to Tomašević K., "the precise determination of the ethnic boundaries of the term'Serbian music' is first in the line of questions to which consensus in musicology practicehas not been established so far." Such considerations entail posing "a whole series of questions in relation to the ethnic and geographical boundaries of the term." It is also necessary to consider the composer's personal sense of national affiliation ... [especially] with respect to Yugoslavism as an ethnic determinant", as well as to consider the view that "due to the dynamics of artists' international migrations", Serbian music was also developed by "composers of non-Serb nationality ..." andit developed „, exterior to its native ethnographic space” (Tomašević 2003, 19-21). Konjović belonged to the latter group of composers, since from 1921-1939 he lived and worked in Zagreb, Osijek, Split, Novi Sad, again in Zagreb; this leads to the conclusion that Koštana as a musical imprint of southern Serbia was mostly composed outside Serbia before the unified Kingdom of Serbs, Croats and Slovenians was formed (1918). His deeply intimate relation towards tradtition, folk songs, especially towards the subject matter and atmosphere of Stanković's play, Koštana, presupposed that Petar Konjović, a native of Vojvodina, a Serbian, a Yugoslav and a cosmpolite would achieve a remarkably contemporary opera piece in the context of development of Serbian and Yugoslav national music in the first half of the $20^{\text {th }}$ century (Tomašević 2004, 73-94).
} 
an essential difference between the choice of harmonic means in the stylization of folk song sand more or less dissonant harmonic language used in the non-folklore episodes of the opera is basedon the polarization of lyric and dramatic principles; thereby, the folk song represents the lyric dimension, while the drama gets full affirmation in the recitativo episodes of dramatic segments of a high psychological tension. This phenomenon of diverse harmonic reflection, as well as its impact, emerges from the different treatment of folklore and other, through-composed segments, in order toachievethe atmosphere or create emotional gradation that leads in waves either to the „local”-temporary culminations, or the global ones of high dramatic intensity. It is álso important to notice that Konjović had considerable knowledge of modernistic dramaturgy and a profound intuition for profiling micro-details and their function in forming the macro-dramaturgy of the piece.

\section{FOLKLORE, FOLK SONG AND ARTISTIC CREATION}

The circle of questions related to the problem of the synthesis of folk and art music is certainly on the top of the priority list of defining the term "national music" within national musicological and theoretical thought in Konjović's era. "Interwining of folklore in art music," Konjović writes, "[is] one important, psychological and logical, expressive manifestation of the creativity of the artistic spirit" (Konjovic 1947, 26). However, even in the invaluabletreasure of this tradition of folklore characters and ideals, Konjović warns that there are significant qualitative differences and that "everything called folklore ... is not one and the same neither by purity, nor value, nor quantity. Folklore, - according to Konjović, - is significantonly if it is pure, if it retained the non-deviant values of its musical qualities, which were created somewhere in patriarchal primitiveness, spontaneously, without purpose, without tendency, simply as a psychological manifestation firmly implanted into the simplicity of a common man (Konjović 1947, 30). It is note-worthy to mention the opinion of Zemtzovsky (Земцовский, Изалий Иосифович), prominent Russian ethnomusicologist, who claims that a succesful and natural transformation of folk music into artistic "without communication with the people (especially during folklore expeditions, in which many young composers participate...), without the direct auditory perception of the folk song (not from the book, but 'naturalistic', village located, first hand!) would not create a new creative tendency..." (Земцовский 1971, 214). It seems as Petar Konjović shared similiar views. He perfectly designed his own "music travelogue", experiencing and comprehensing folk music as a natural source of his artistic speech. The true example of this is the cycle of songs Moja zemlja (My Country) - as a specific predecessor of his future steps towards the music drama.

In the concept of the great folk music drama Koštana, as a piece of a high artistic ideal, later acknowledged beyond our borders (Czech Republic: Brno 1932, Prague 1935), Konjović was, quite logically, inspired by folklore - particularly the folk song. The songs that reflect the depths of the folk spirit of Southern Serbia, were the source ofwast expressive means and creative impulse for creating the broad music-dramatic images. Konjović chooses those folk motifs that "by shape and content represent a more real, higher value" (Konjović 1947, 30), but are alsosuitable for integrating into a music-dramatic pieceand by processing folk songs through quotation or stylization, he achieves a higher form of upgrading, giving them an overall artistic sense. The use of the songs as a musical-expressive genre means is present in the characterization of the central figure of the opera. It is a larger number of songs in question, since - as Yarustowsky (Ярустовский Б.) writes - it is necessarythat the main protagonist 
"throughout different scenes... changes and, therefore, [he] cannot be completely characterized by one vocal tune, even of a best choice" (Ярустовский 1953, 119-120).

Due to the content and its local atmosphere that Konjović depicts, it is understandable and logical that he turns to the national folklore genre of songs and dances of Southern Serbia. The genre of songs in his opera played thekey role in creating a specific kind of musical fresco from Vranje. The style and value of this music drama was characterized by another great Serbian composer of that time - Miloje Milojević - who wrote: "in Koštana ... Konjović managed to set a new style in our operatic music, based on "sevdah"3 but elevated to the highest artistic spheres. This high artistry of the national (sevdah) tone in Koštana is the heritage of invaluable worth" (Milojević 1933, 78).

In Koštana Konjović develops the realism of Mokranjac's artistic thought ${ }^{4}$ to the level of a creative method, reflecting through music the lives of common people, characteristic features and localmentality, striving for the very essence of the national being and identity. The folk song had a significant role in dealing withissuesof nationality, local coloring and images of folk life, as well as in the architectural design of the opera.It is the way in which Konjović applies and processes the folk song thatbuilds up the position of Koštana's role and places her in the center of the opera. She is not only the dramaturgical center of opera, but also the axis of the drama. She is the driving impulse for all dynamic relations between other protagonists (Koštana - Stojan, Koštana - Hadži-Toma and finally Koštana -Mitke), from which the plot develops towards the main culmination in the fifth scene (Drunk morning), followed by the denouement of the drama.

\subsection{Dramaturgical characteristics of the songs in the music drama Koštana}

As the means of a specific gradation and dynamization of Koštana's role, Konjović compositionally builds up herrising from the folk song of Vranje through the type of vocal interpretation "singing in singing". How does the composer achieve this? In the first scene, the main role is introduced only by sound behind the scene, through the song "Dude, mori, Dude" by other protagonists. The songs "Jovane, sine, Jovane", "Zašto, Sike, zašto" and "Stameno, mori, Stameno" in the second scene, and "Na sred sela" in the third, represent Koštana and the other protagonists "becoming an inseparable part of the psychological and dramatic development" (Ilić 2007, 101-102). The next song, "Tri put ti čukna", which Koštana chose to exhilarate old Hajji, presents a "Carmen of Vranje", seductive, passionate, highly emotional; her performance provokes fatal consequences for male actors on scene, while the song "Devet godina mina" brings a dramatic turnover and the downfall, leading towards the tragic destiny in which Koštana is to suffer for her beautiful voice, appearance and opulent beauty. Tending to create a dramaturgically clear fabulae line, Konjović entrusts the heroine of his opera with musically and dramaturgically well-chosen and effective seven songs; theyare exposed in all the scenes except in the fourth ("U kućerku Koštaninom"), which he conceives as a recitative-arialike deepening of her psychologically devastating state of mind and soul. In considering the procedures of musical dramaturgy and the concrete function of Koštana's songs in Konjović's musical drama, we start from the figure of Koštana - agypsy singer, who performs songs on the order of the representatives of the higher hajji social class. This is precisely one of the dramaturgical keys for connecting Koštana's songs with drama

\footnotetext{
${ }^{3}$ Local term meaning lovesickness, suffering and melancholic feeling for the youth that passed.

${ }^{4}$ About what Vojislav Vučković, Milenko Živković, Petar Bingulac and others wrote.
} 
flow.In addition, "Koštana is in this drama identified with her voice - asymbol of beauty and youth" (Stamatović 2002, 81). That is why her voice and beauty, in addition to the lyrical role in creating the atmosphere and conveying the local coloring, have an obvious causal function of the emotional-dramatic reactions of the maleprotagonists in the opera: Stojan, Mitke and Hadži-Toma. ${ }^{5}$ As anactive factor in the dramatic personality of her role, but also a powerful stimulus and initiator of the further action - as the composer himself confirms it - "... the motive of the song becomes a tragic motive of lament for life and joy, and it is as such reflected [to other characters], especially in the relationship with the other main protagonist, Mitke" (Konjović 1947, 109).

There are only three songs in the musical drama Koštana performed by other characters. Since they are logically interwoven into the main line of dramatic action, they are by many parameters different from Koštana's songs. The songs "Eva Kaurkinja" and "Da Ti Znaš Mori Mome" are being sung "by order" presenting in dramaturgical terms the stimulus for emotional-psychological progress in psychologizing the characters of Hadži-Toma and Mitke. While the first song sounds like it is breaking the outer firm shield of Hadži-Toma ("Gets straight to the heart!") and brings back Mitke to the time when he and Koštana's mother Salče were young ("Salče, old Gypsy!"), the other one especially moves Mitke ("sing... like you are sorry for yourself... sing, darling!") bringing in the foreground the motive of "lament for youth" - the basic feeling of his character, which at the same time is one of the key elements in the central axis of the drama.

The third song - "Bula ${ }^{6}$ Mlada", performed by Hadži-Toma (second scene, b.3/153), occupies a special place in Konjović's drama, both from the point of view of dramaturgy and of the radical reduction of musical means by which it is realized. The tragic verse toneof this "hard and old" song that brings back Hadži-Toma to the grief of his own youth is a complex metaphor which, in the perspective of the dramatic flow, anticipates the possible, and, finally - the expected tragic end of Koštana herself ("Young woman, after the wedding, as soon as she lied down, died immediately"). ${ }^{7}$

\subsection{Musical-dramatic characteristics of Hadži-Toma's song "Bula mlada" (Young woman)}

It is important to point out that the musicologist Stana Đuric-Klajn considers Konjović's drama as the "peak of the composer's opus" in which he succeeds to "raise the melancholic (sevdah) pathos to a higher artistic degree and to design itin contemporary European style", while "Pesma o Buli" from the second scene, is seen "as an original contribution to such a style" (Đurić-Klajn 1962, 655-656). Another of our musicologists, Nadežda Mosusova, who undoubtedlygavethe greatest contribution to the study of Konjovićsopus, states that

\footnotetext{
${ }^{5}$ However, the song "Jovane Sine" alsohas an emotional-psychological (not dramatic!) impact on female characters - on Magda, in a way that it made her cry, primarily by the interpretation, and by the choice of the song and its content, as I. Stamatović writes.

6 The term "bula" stands for the old Turkish word for the woman of the Muslim religion, that is, according to Vujaklija's interpretation: "Turkish woman" (Vujaklija 1980, 136).

${ }^{7}$ Characteristics of the third song in the musical drama- "Eva Kaurkinja" - which is not performed by Koštana nor the choir but by Salče, were discussed in the paper"Artistic stylization of the Great Coček Dance under the light of the interpretation of the songs Oj Devojka Mala and Eva Kaurkinja in the musical drama Koštana by Petar Konjović (Bartf 2018 Proceedings, in print). In addition to performing the song "Da Ti Znaš", Alil is joining Kostana in the song "Devet Godina Mina" because of the gradation of soundness and expression. Stojan, yet, in duet with Koštana performs a love song "Dude Mori, Dude".
} 
the "Pesma o Buli" is "Turkish and its melody is not familiar" and that "the simplicity of the orchestral accompaniment, which is reduced to one single instrument, contributes to the expressiveness of this moment more than anything" (Mosusova 1971, 162-163). Konjović, with a particularly refined aesthetic feeling resolved this dramatic complex moment - a kind of "a hub" in the drama. Knowing the tragic outcome of the song, Koštana's mother, Salče, hesitates to indulge Hadži-Toma's wish to sing it, thus preventing a further gradation of pessimistic feelings in the key protagonists. Therefore, the song is performed by HadžiToma himself, but only spoken (not sung!) as a quotation of the text fromthe play by Stanković. This is actually the only song that he performs, where Konjović musically reflects the content of the spoken text of Hadži-Toma from Stanković's original work and builds it up to the formal pattern of the song. ${ }^{8}$

The song "Pesma o Buli" it self was harmonically prepared with a tonal mutation from A-flat major in the A-flat Balkan minor, with which Konjović achieved a significant darkening of the harmonic coloring. Choice of A-flat minor, - the tonality of i.e. the Funeral March from Beethoven's Piano Sonata op. 26, confirms the composer's coloristic understanding of the tonal color and the tendency to use its symbolism to accomplish a striking expression and sense, the connotation of the gloomy mood, feeling of emptiness and lack of meaning. The tonal plan of the song leads to the B-flat minor (the parallel of the major subdominant or the tonality of the second degree of melodic minor) and to E-flat minor (the minor dominant), as close tonalities from the downward side of the fifth circle, complementing the pessimism of the dark colors and the severity of the disastrous events the verses narrate.

In a previously affirmed, clear tonal center in A flat, the introductory arabesquesin flutes based on the tonic triad with the added sixth and final melodic stops on the IV or II degree of the folklore scale - thatis, the Balkan minor - bringmystical, oriental-exotic resonance. In the center of further thematic development in the flute, there is the initial motive of a minor triad with added major sixth that creates mild tension in the tritone relation with the tonic third, symbolically denoting the mental anxiety. Due to this, the relative chord consonance in the conditions of the previously affirmed center works more than enough "tonic". However, in later phenomena, with changes in tonality, without concrete functional determinations, the potential tonic stability, impressionistically weakened by the addition of a sixth, will only indicate the manifestation of a certain "harmonic feeling" (Gulyanitskaya 1984 , 24). Here we cannot talk about modulation in the traditional sense, but about the tonal spheres due to a certain "harmonic feeling", that are created by simple exposure of motives at different tonal/tone centers, but without tonal confirmation. The term was introduced by the Russian theorist Tyulin, Y. (Тюлин, Юрий Николаевич) and refers to interval relations which, according to Gulyanitskaya (Гуляницкая, Наталия Сергеевна) (Ibid., 24), form a certain "harmonic feeling in both horizontal and vertical interaction". In the song "Bula Mlada", the "harmonic feeling" arises from the dialogue of the solo voice and flute, only occasionally accompanied by the bass tonesin the harp. Tonality is expressed with tonic function without classical confirmation i.e. a harmonic chord progression that would indicate functional gravity to the tonal center. Actually, the fluidity of tonality is fully in function of creating the mournful, requiem-like emotionality of the song's content.In

\footnotetext{
${ }^{8}$ Stanković B. in his literary work entrusts Hadži-Toma even with and a few Turkish verses of this song, which Konjović gives up.
} 
accordance with Konjović's creative poetics and aesthetics in the shaping of musicaldramatic flow, there was no place here for tonal stability and undeniable tonal determinations. Perhaps the most appropriate name for the tonalities here would be "floating tonality", the term that Vlastimir Peričić used for parts of the music flow with "constant transition to new tonalities, none of which is fixed" (Peričić 1968, 55). However, in the case of harmonization of "Bula Mlada" song, it cannot be discussed about this type of tonal vagueness, where according to Peričić, "tonic usually does not even appear" (Ibid., $55)$; in the absence of the key elements that affirm the tonal center - functional gravity and harmonic dynamics built on the dissonance-consonance contrast- theharmonic plan of the song still affirms the three tonal-colored spheres, first of all, following the steps of shaping a mystical, oriental spirit saturated sound image.

In the instrumental accompaniment, radical reductionism was conducted in order to maximize the concentration of expressiveness, mysticism and timelessness of the moment. In this way Konjović achieves a musical-poetic expression that has no similarity to any segment of the opera, testifying to the moment with a unique, deeply pessimistic and compressed expression, which at the same time represents a specific anti-climax in relation to the musical surrounding of the drama in which it occurs. A reliable testimony of the composer's dramaturgical remarkable skillis shown in terms of dramaturgy, since in the moment of the most intense emotional-psychological turbulence of the protagonists he reaches out for the effectiveness through sharp contrast, but by reducing the instrumental part to a minimum which, in this case, replaces the lavish orchestral palette with the dialogue of the vocal part, intimate arabesques in the solo-flute and soft arpeggio echoing of the harp.In relation to harmony, this compositional-dramaturgic procedure by Konjović resulted in a harmonic vertical that can be presupposed bythe linear interval interaction in the vocal melody and the vertical in relation to solo voice and accompaniment. By applying tonal changes during the development of the song, but even more "mutations" of scale types within one, tonal or modal center moving from the harmonic and Balkan minor to the Dorian mode, Konjović successfully creates the harmonic and coloristic nuancing of the musical flow as a presentation of emotional and psychological changes in the emotional and psychological status of the soloistin accordance with the content of the song text. From the initial recitative intonations at the fifth scale degree, the vocal melody develops along with the dramatization of the text and in dialogue with lapidary comments of the flute. The instrumental sound is enhanced in the lower register by the occasional accompaniment of the harp in octave flageolets, and the tragic effect in the 'conclusion' of the song is underlined by the cold gamma of the colors of wind instruments: clarinet, English horn and horn.

Let us now look in detail at the harmonic plan of the segment including the song "Bula Mlada". The accentuation of the bass fundamental tone B-flat in the harp and the alteration of the scale sequence in the solo part redirects the musical flow into the B-flat minor (b. 6/153). The associated harmonic feeling, modeled by the solo part (b. 7/153) is intensified bythe bass tonesin the harp in a sequence of constructing degreesVI - V - I of the Balkan minor variant, somewhat after VI - IV - V. Interrupting the song by asking the question ("Does she know that song?") causes a new emotional-tonal sphere with restlessness intonations (in the flute part) on the subdominant with added sixth in E-flat minor. Salče's response pronounced with fear,is followed by the harmonic progression of the conflict: $\mathrm{II}_{\mathrm{LDM}}$ - ${ }^{+} \mathrm{III}$ in E-flat Lydian major-minor key. The lament text in continuation of the poem, "she is dead ... and the mother-in-law thinks ..." comes, however, on the conflict vocal intonation of 
the ascending diminished fifth. However, the sequence of the chords II $-\mathrm{D}-\mathrm{t}$ in harmonic minor clearly confirms the tonal center.The new, conflict triton descending and ascending intonations in the interpretation of the text that tragically affects the soloist ("she does not leave the room yet"), increase the dramatics and expressive-acoustic tension, redirecting the musical flow into B-flat Balkan minor. The minor triad with the characteristic added major sixth in the flute part accompanied by of the same chord in the harp are the elements for forming the new tonal center. The upsetting verses of the concluding part of the song "she... dead... and pure" cause a new tonal-psychological shift in E-flat Lydian major-minor key with exposing the initial theme on the tonic with the added sixth. The tonal center is already confirmed in the next bar due to the link and mutual effect of the subdominant and dominant tritones, from which the crossed dominant tritone arises (b. 9/154). In a tragic, tense expression of agony and restlessness, Hadži-Toma's recitative seems like being petrified at the F tone ("a male hand did not fondle"). The further musical flow brings the expressive and dynamic anticlimax with the startling "intonations of restlessness" in the flute part creating the thematic encompassing of the song, while the modulation to the third related $\mathrm{B}$ minor (enharmonically) over the mutual tone F-sharp G-flat marks the interruption of the resigned atmosphere and an introduction to the replica of Salče.

Example 1 (The mill of Sobina village, b.3/153) ${ }^{9}$

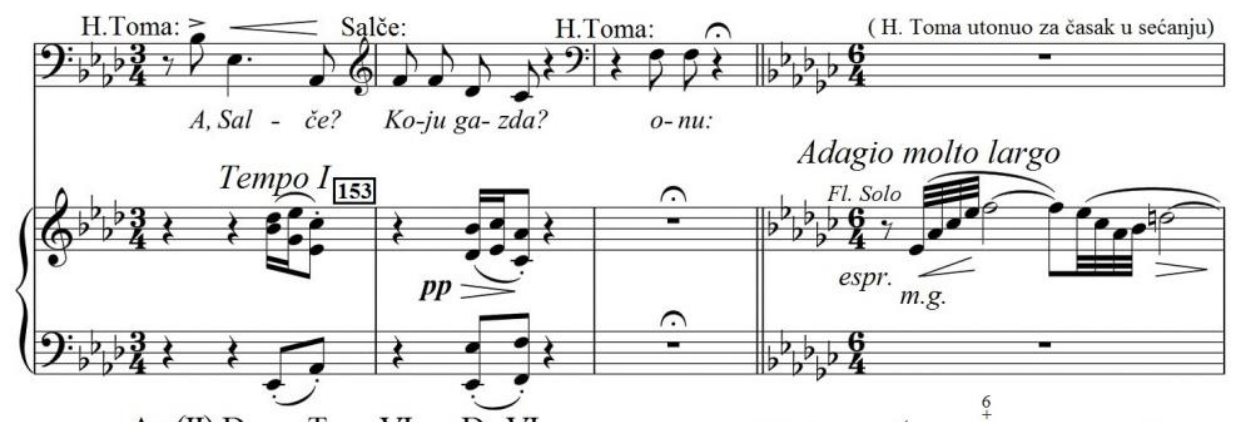

as -balkanski mol: $\mathrm{t}$
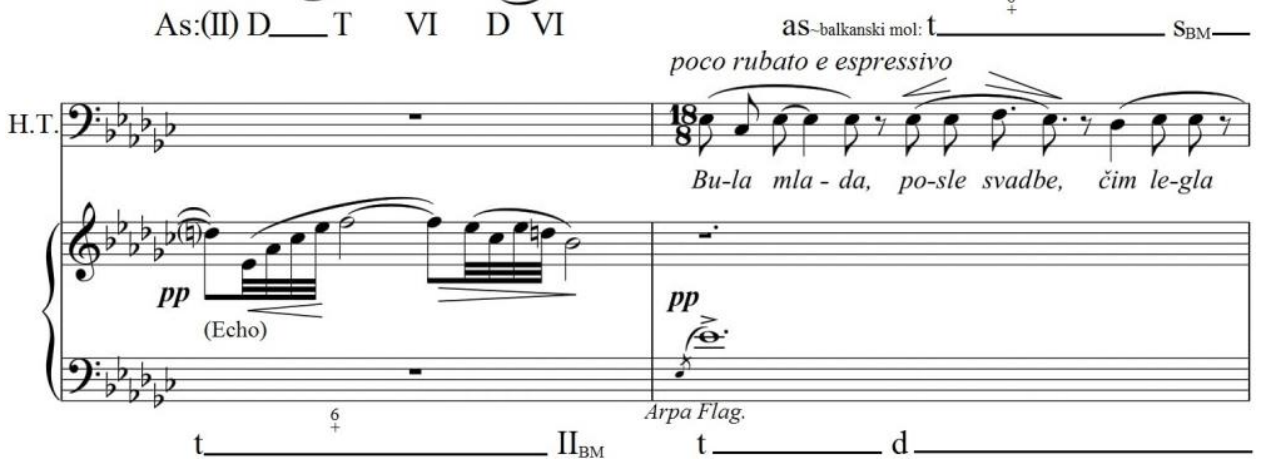

\footnotetext{
${ }^{9}$ The denotation of the key in the $4^{\text {th }}$ bar of the example is A-flat Balkan minor.
} 

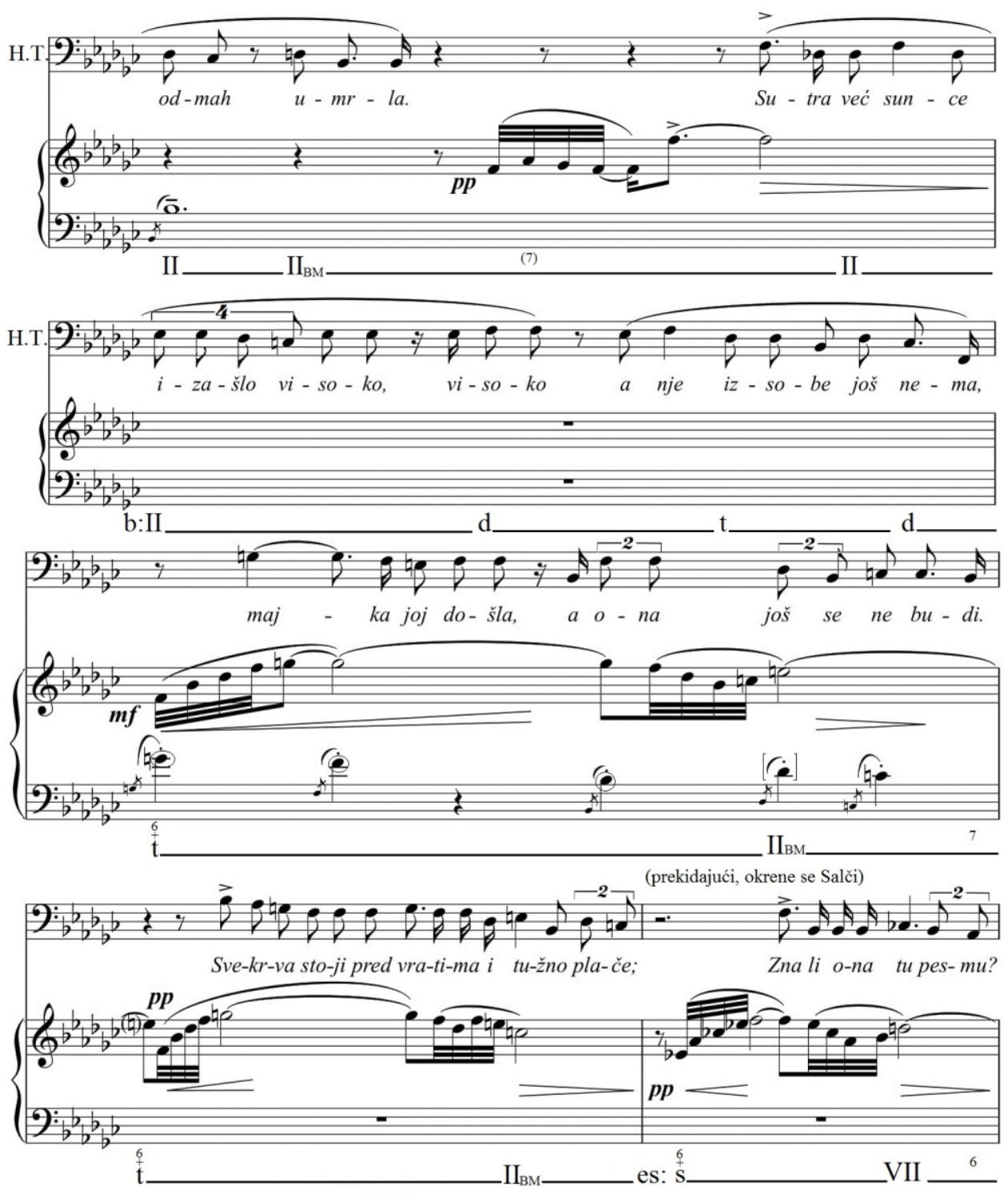


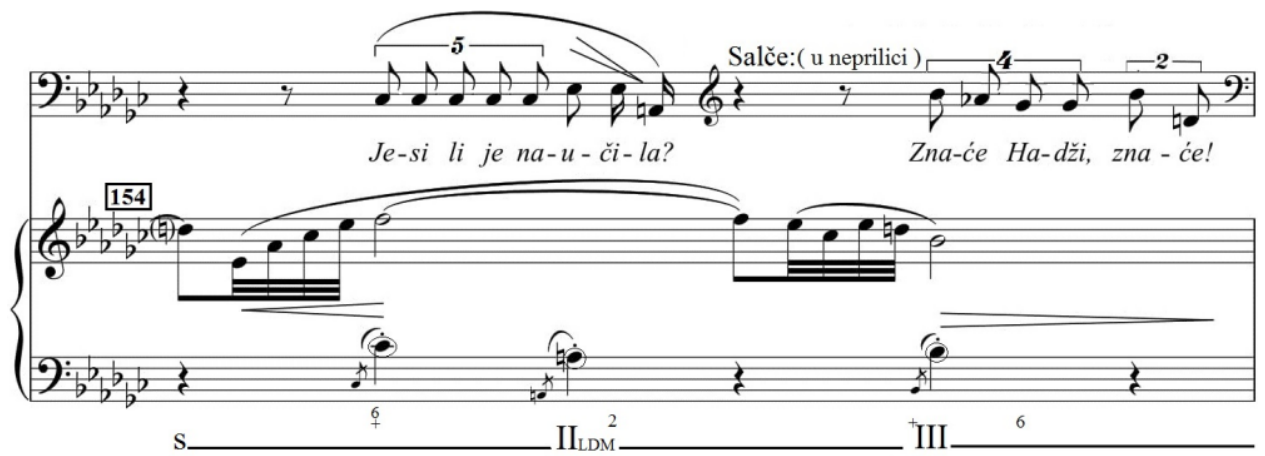

H. Toma:(nastavlja kao sam za sebe)
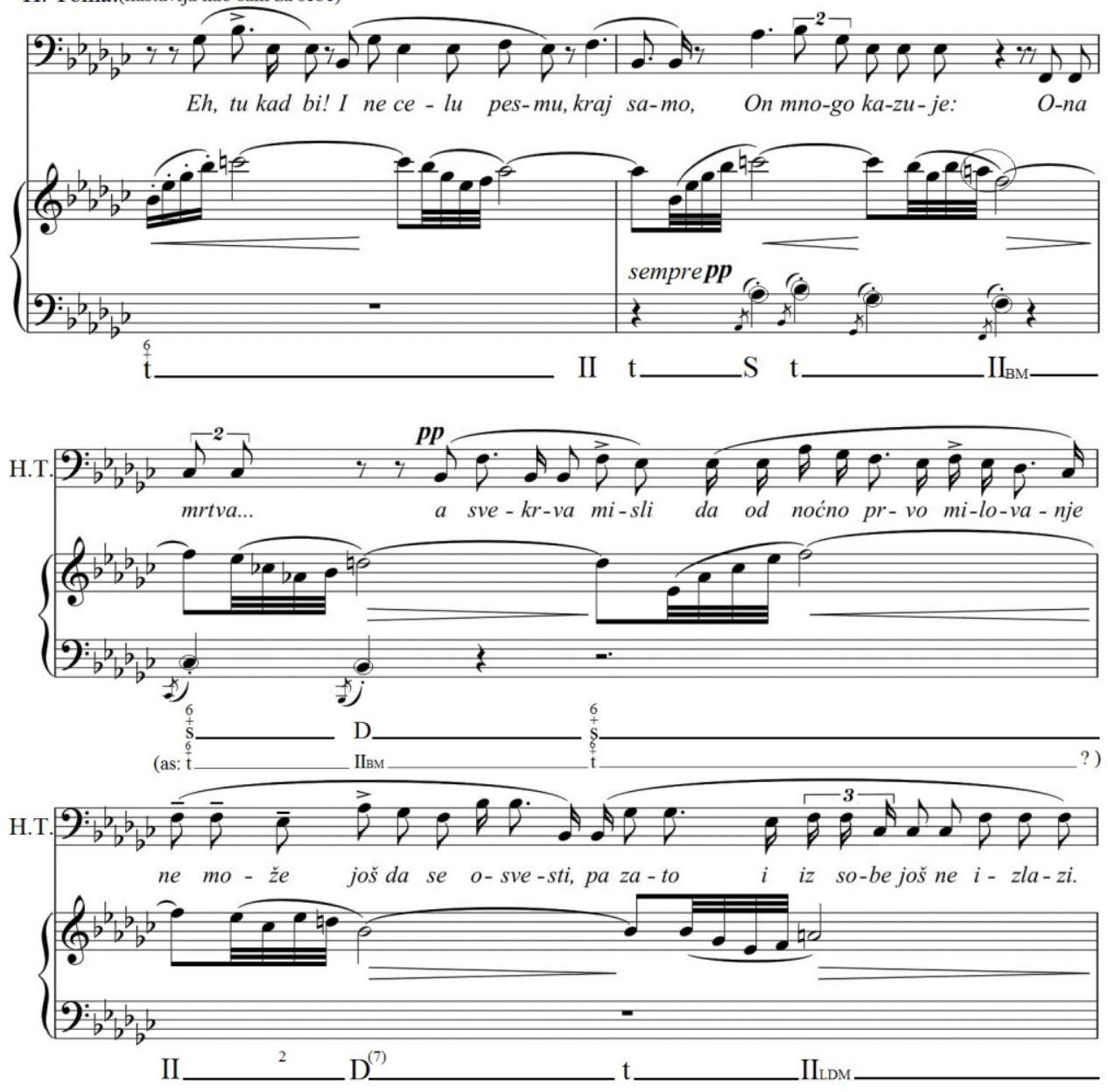

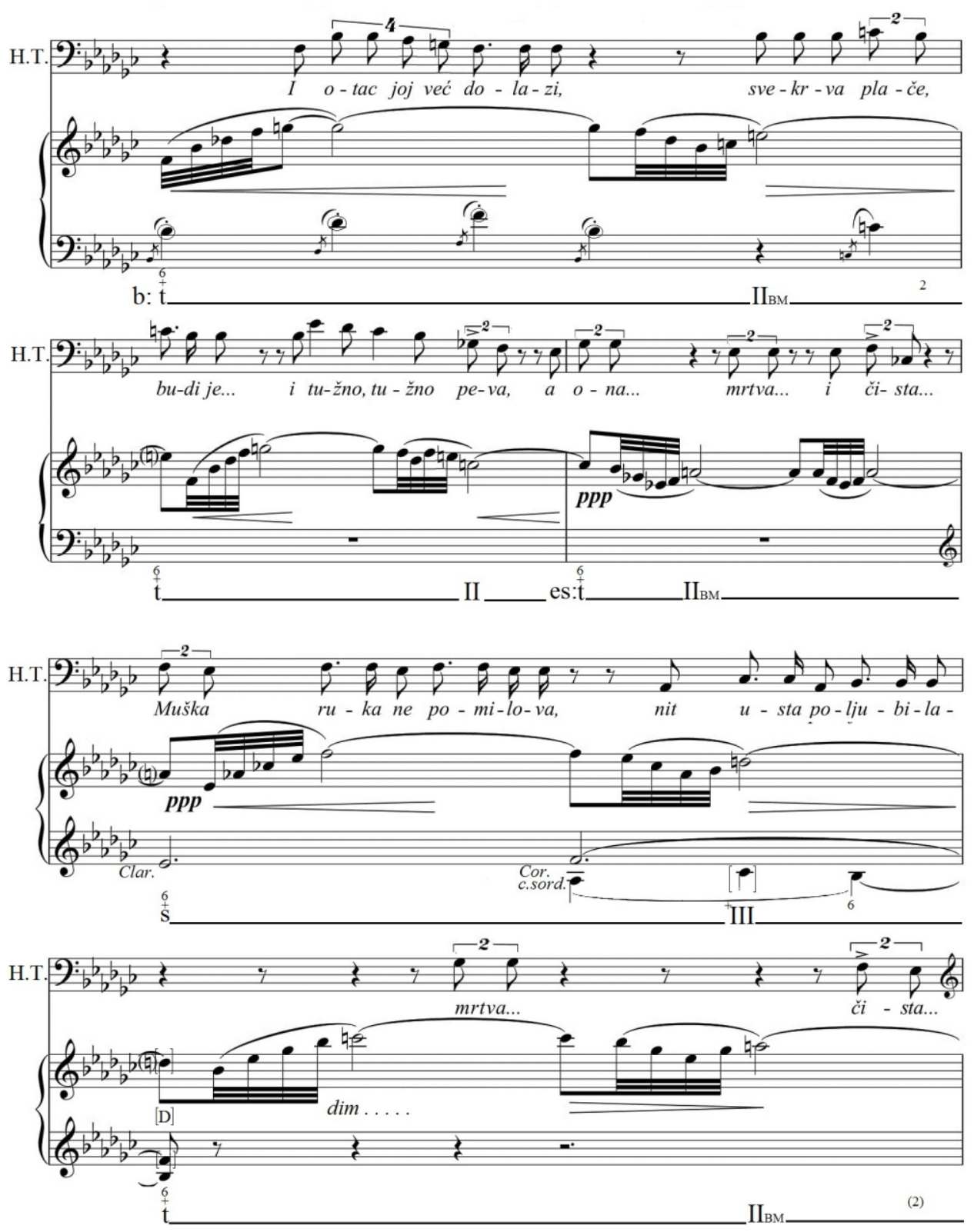


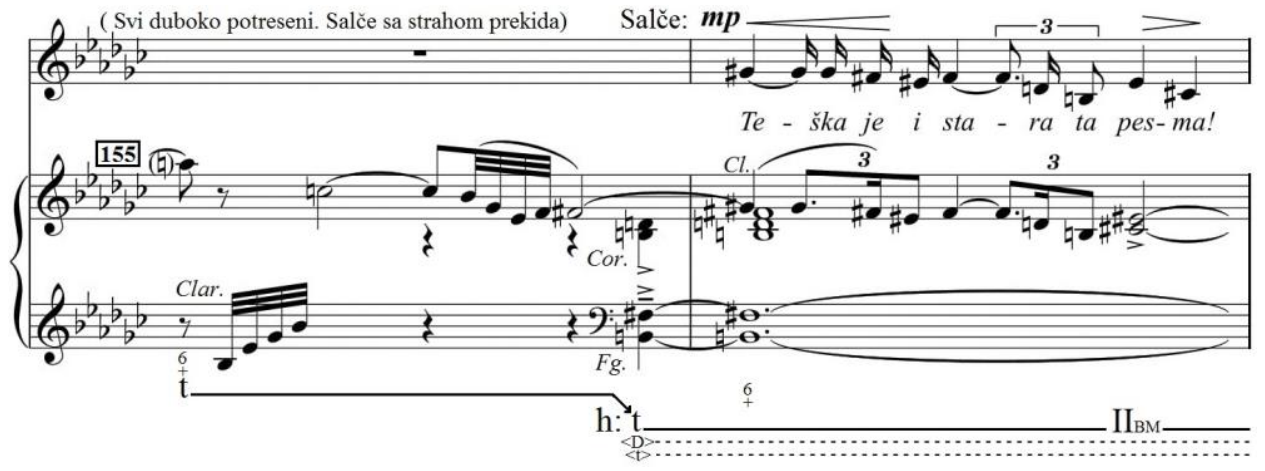

\subsection{Musical-dramatic characteristics of Alil's song "Da ti znaš"}

The harmonic atmosphere in the song "Da ti znaš, mori, mome" Konjović achieves using completely different means. His choice now consists of empty perfect fifths in parallel movement taken from the beginning of the scene"drunk morning". A similar principle of bringing in the dark-light tonal effectis achieved when the long harmony of the $\mathrm{D}^{9}$ in B-flat major by lowering the ninth provides a mutation to the darker coloring of the same-tonekey. The song "Da ti znaš" performed by the gypsy named Alil starts behind the stage, so that it organically represents the continuity in creating the initial ambience of "Mitke's scene". The very beginning of the poem points to a certain pervasion of B-flat minor and Phrygian major (dominant minor).The pervasion of the fifth related tonalities is manifested by the action of the variable functions, where the initial dominant of the B-flat minor centralizes the key of F Phrygian major and draws the following VI degree (of B-flat) into its sphere of action as the Phrygian II degree. However, the preparation of the song on the long lasting dominant ninth chord of B-flat minor, as a five-tone chord structure characteristic of the dominant rather than the tonic, defines the tonal center. The vocal part of the song about the "lament for the youth" is doubled in the clarinet with additional melismatic decoration; it is possible that Konjović chose this instrument to illustrate the typical arrangement and style of gypsy orchestras of recent urban practice. This will be confirmed at the beginning of the second stanza, where the composer conducts a gradation by exposing the thematic material in a stretto type, followed bya complementary type of exposure of the theme between the soloist and the other unavoidable instrument of agypsy orchestra - the solo violin. Gradation and sound dynamization also involve filling the empty fifths of chordsin the first stanza up to chord structures from the beginning of the second stanza. Octave doubled empty fifths of the first stanza and their chromatic parallelism of a specific sound color, Konjović assigns to the male choir in mormorando, which represents a sonority over which the solo melody develops. The role of choir accompaniment accordant to the nature of the song was differently realized in relation to the previous two Koštana's songs, without dashing rhythmic formulas. Subtly coloring the closure of the song, composer complementsthe described empty fifths into chord structures by introducing the female choir in the cadence and its repetition. On the other hand, as a contrast, the accompaniment of the second stanza begins with a six-voice choir with a variable number of parts that will be reduced during the song to a three-voice male choir, but only as a fine sound contrast (in only two bars) until the re-establishment of the full soundness of the mixed choir. 
After the initial deceptive harmonic shift $\mathrm{D}^{9}-\mathrm{VI}$, Konjović gives a soundly unusual harmonic solution in the form of a strikingly accentuated progression of parallel fifths, partly chromatic, with the "harmonic feeling" created by fifth chord ingredients in the form of incomplete chords: chord of the natural seventh degree, minor Lydian chord, and the tonic as a major triad. The parallelism of fifths in terms of dramaturgy gives the impression of archaism and a feeling of emptiness over something that was long past and will not be regained, while the latent harmony of the natural seventh degree chord points to a mode sound of Aeolic color. In relation to the associated modality, the next chromatics of A-flat $\mathrm{A}-\mathrm{B}$-flat in the bass line, doubled by parallelism of perfect fifths, is a part of the pervasion of the modern harmonic expression with the romantic style in the nuanced modalchromaticcoloring of the song. In the partially chromatic movement of the bass line: $\mathrm{F}-\mathrm{G}$ flat - A-flat - A - B-flat, the forth tonal relation of F-B-flat $(\mathrm{V}-\mathrm{I})$ with the final energetic potential of the major spirit, is obvious. However, even during the tonic of the B-flat major, a passing triad of the sixth degree chord occurs in the accompaniment as an announcement of the upcoming tonality, while in the vocal part the fifth interval is highlighted as the tonal frame T $-\mathrm{D}$. The unusual sensual-sound value is created in a six-bar phrase, where Konjović skillfully shows the ability to directly interweave first the tonalities of the same tonics, and then with the parallel keys during a small musical space. At the same time, by delaying the resolution of the final melodic tone $g$ as the second degree of F major and the fifthof the dominant chord, which could be potentially perceptively concluded from the melody, Konjović endsthe phrase with the unusual semi cadence $\mathrm{t}-\mathrm{VI}$ in $\mathrm{G}$ modal basis. The described modal archaic notion was not applied only for compositional-technical reasons for a more modern approach to folklore material, but was primarily performed in order to achieve the specific musical-dramatic expression. The use of secondary degree chords in the next three-bar cadence repetition confirms the G Aeolic modal basis.

The emancipation of the very beginning of Mitke's vocal replica ("Sing, Alil...") in the form of a suspension and its resolution to the added second, with a chromatic confrontation with the third of the VI degree chord, indicates a more contemporary approach to vocal speech, as well as the shift of the (tonal)-modal center to B-flat major, followed by a subsequent mutation in B-flat minor. Departing the dominantas a tonal support, represented withits fifth, theparallelism of empty fifths doubled in octaves leads shortly to the uncertainty of the tonal center (b. 3-4/206b). The tonal orientation is dramaturgically causally induced by Mitke's exalted reaction in which the attitude of the higher Hajji class toward gypsies is enlightened ("The truth is that your face is a face of a gypsy, but you have grievous eyes..."). The use of the chord sequence of empty fifths of the Polar chord, complemented in the vocal part with the minor third, the mediant and tonic ninth chord $\left(\mathrm{Ds}^{9}\right)$, and the subsequent empty fifths, suggests that the vertical treatment of empty fifths from the beginning of the scene relates to Mitke's inner world, lonely, empty, purposeless. The unstable tonal basis until the beginning of the second stanza is re-established by the circling of empty fifths around the dominant fifth, as a tonal determinant. 
Example 2 (Drunk morning, b. 2/206a)
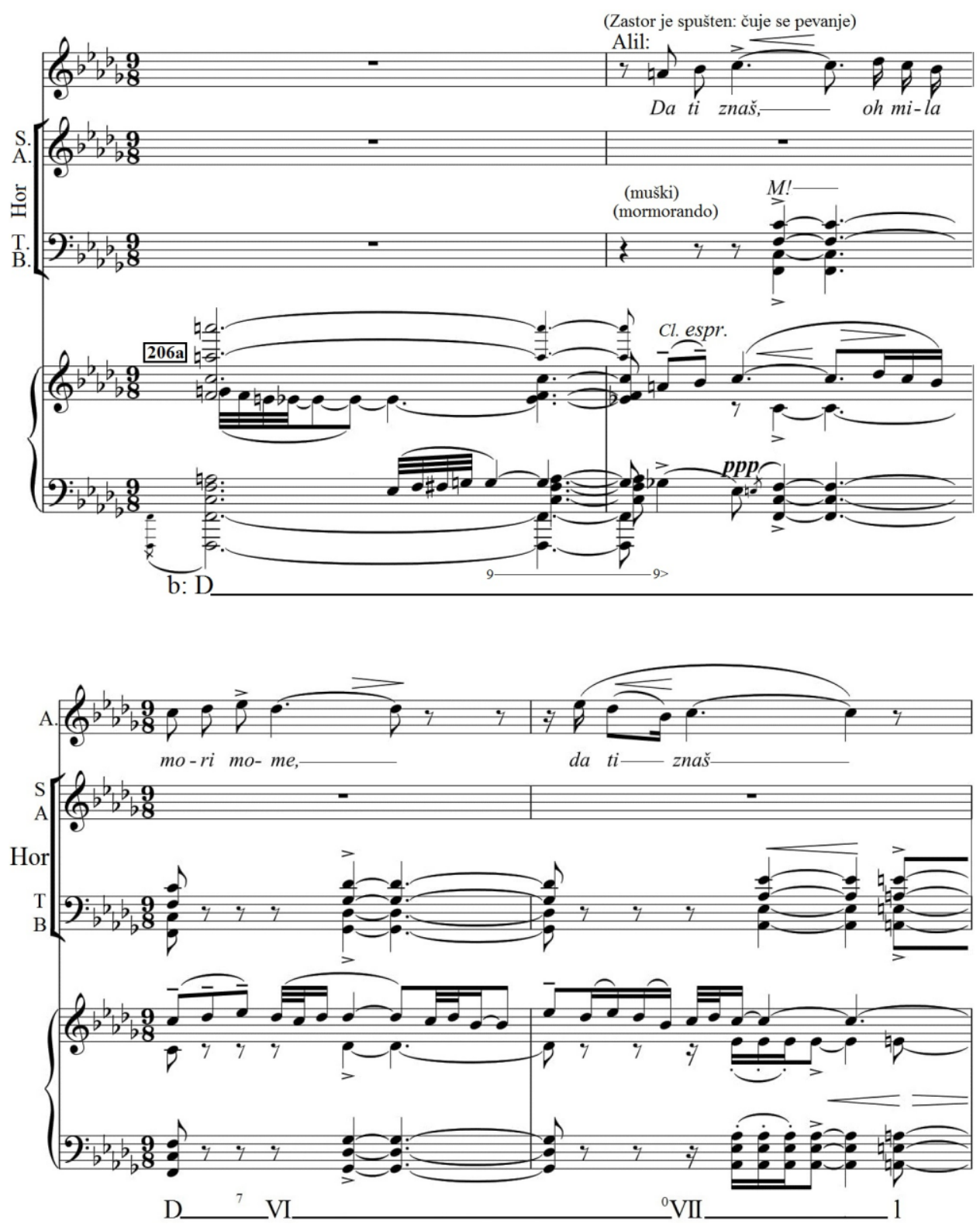


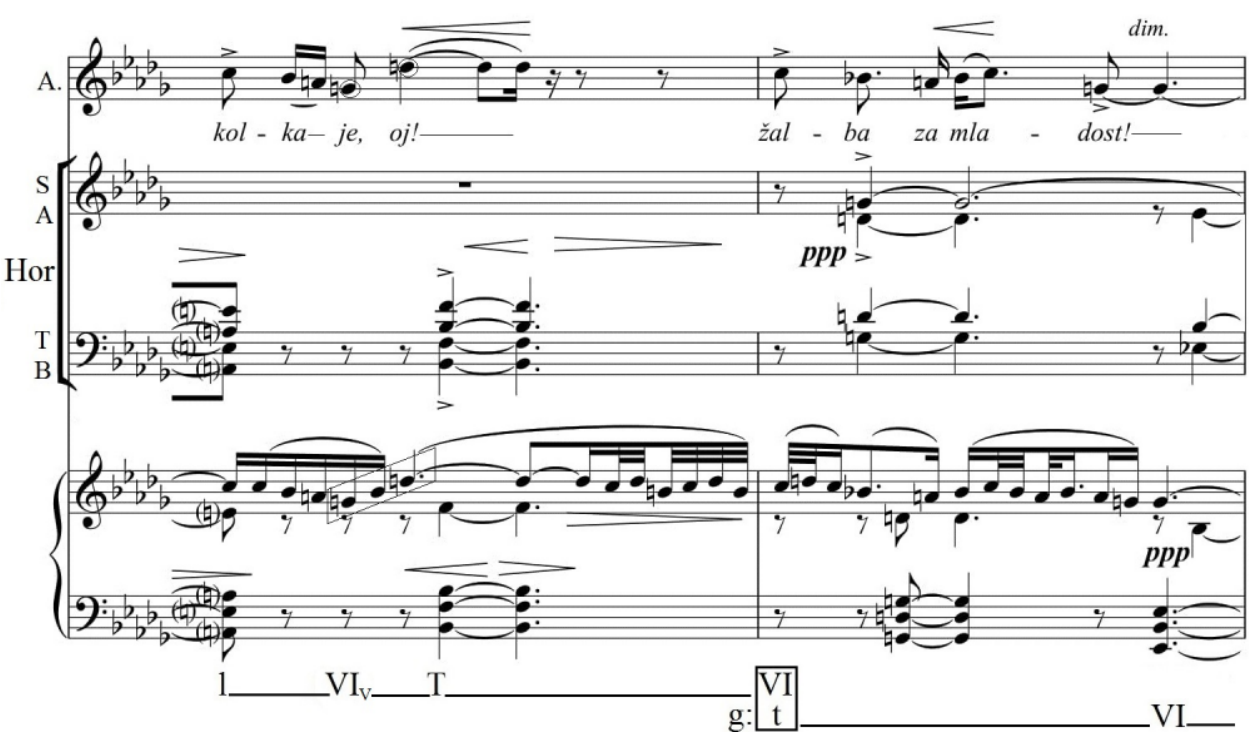

(Još je skoro sasvim mrak, sagorevaju fenjeri. Jedva tek sviće. Pred kućom bašta. Mitke sedi na levoj strani, na klupi uza zid. Oko Mitka leže čočeci i slušaju.)

(Suprotno Mitki na drugoj strani leži Koštana podlaktavši glavu na obe ruke. Alil je blizu Mitka i peva.)

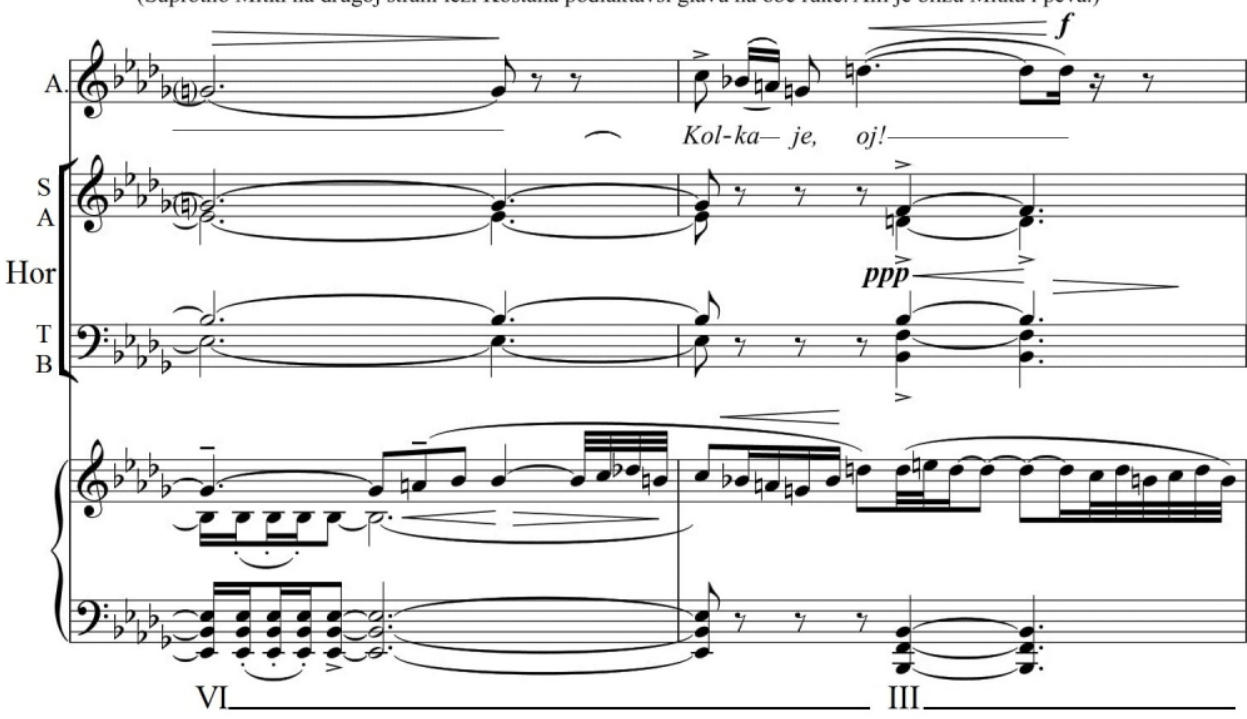



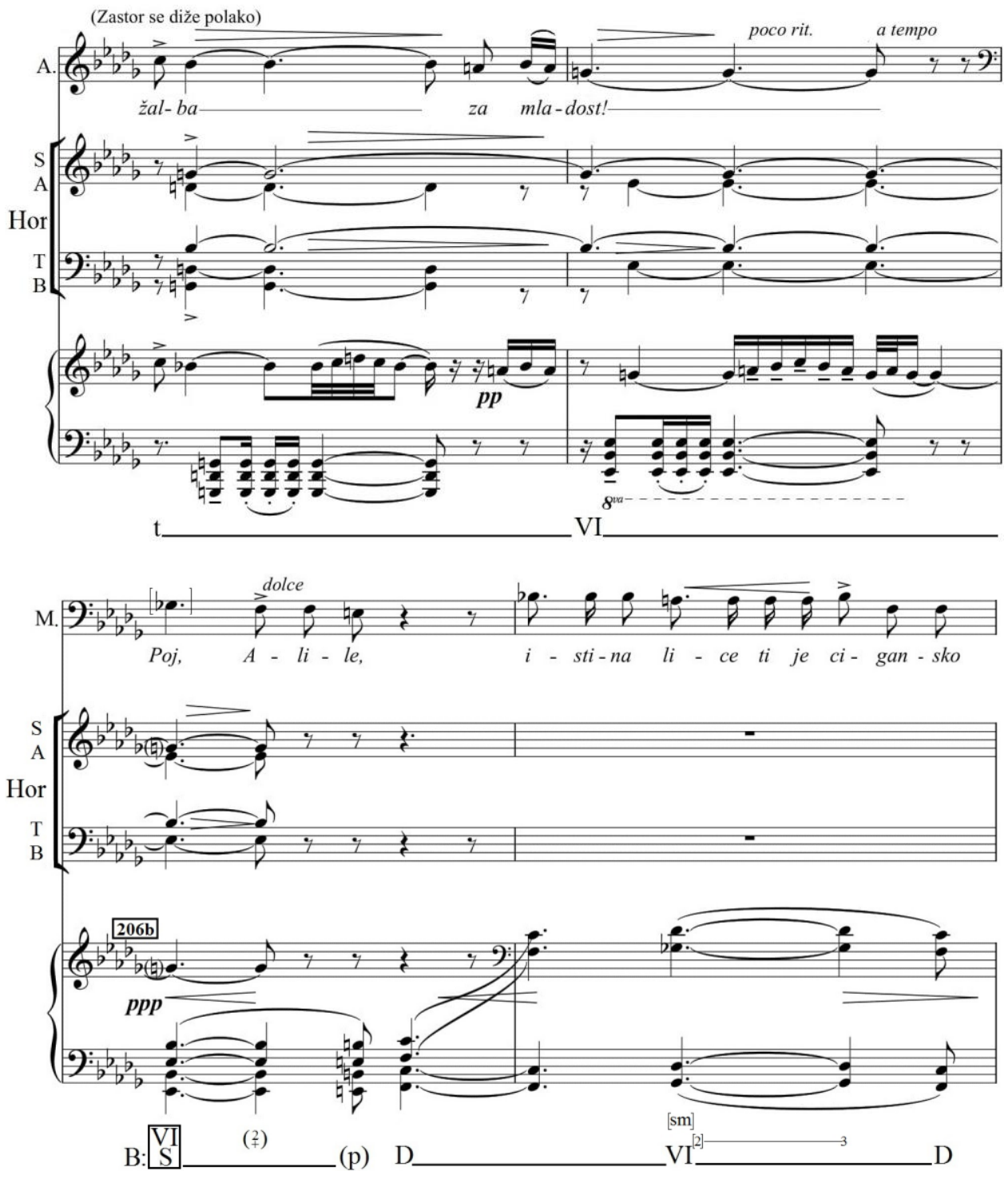

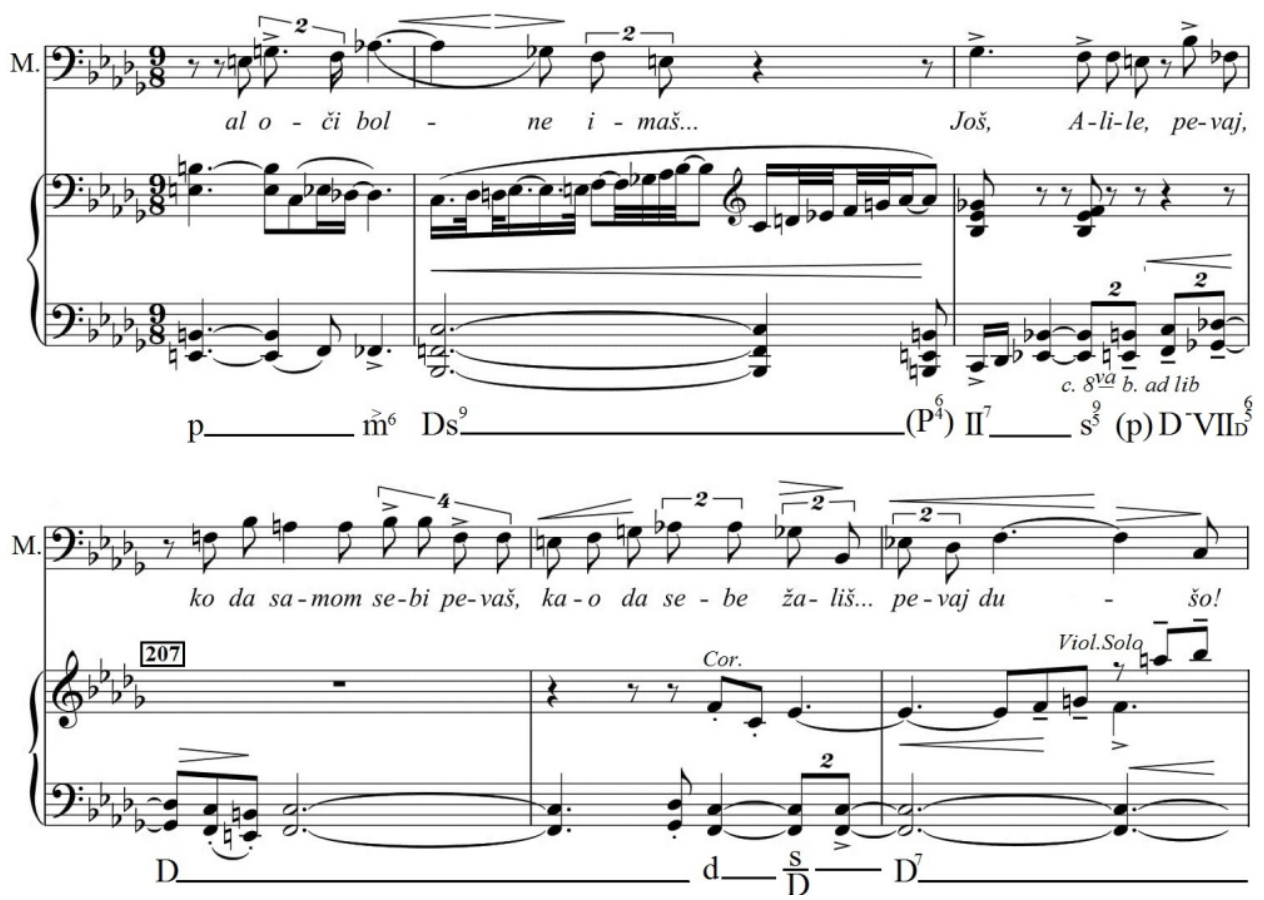

\section{CONCLUSION}

By integrating the song into a drama as a part of a subject line in which he had a rolemodel in the original, starting piece of Borisav Stanković, Konjović achieved an extraordinary dramaturgical balance in terms of the spirit of a modern music drama. This brought him closer to the expression of the musical-drama realizations of Leoš Janáček, whom he had appreciated in a great deal. It is interesting to recall here Janáček's words when he says: "If, during the centuries, the Roman choral showed such a decisive influence on the development of Western music, then I am convinced that the Slavic song will dominate the works of future music in a similar way" (Fogel 1982, 73-74). Konjović seems to have this idea in mind, believing, like many other representatives of his generation, in the inspiring power of the musical South of the Balkans as still unknown and unconquered territory in the corps of artistic music of Europe and the world. Therefore, we believe, Konjović, by choosing the songs for Koštana, selected those songs which, according to the ideology of his time, most accurately reflected "the essence of the national spirit and feelings", in the geographical area Vranje-Veles-Štip, as the locations and origins of the songs themselves. The composer's choice was fully justified, since it stemmed from the desire to create a unique atmosphere of local coloring in a drama, fully compatible with the location of the drama events.

It is important to remind that Konjović, following the spirit of romantic aesthetics, understands choir songs as an opportunity for expressing the collective voice of the people, while on the second level, closer to modern views, he experiences solo songs not only as a musical nucleus, but primarily as dramatic and psychological points suitable for the exposure of the current personal psychological-emotional states of the soloists, which 
simultaneously trigger and direct the dramatic development. It is interesting that Hadži Toma's song-story, actually dirge - "Bula Mlada", is composed with the intertwining of the specific scale of the Balkan minor and the Lydian major-minor with the changes of the scale focus from A-flat to the tonal center E-flat.The selection of these "low" Orientalfolklore scale types of specific expressiveness, unambiguously indicates that Konjović treated certain (modal) tonal spheres from a coloristicand semantic standpoint, emphasizing musical-dramatically certain gloomy moods and motivating new phases of the dramatic events. Also, the intertwining of the same-tonic and parallel tonalities with the mild modal coloring of the Slavic national provenance in Alil's song "Da ti znaš" is based on the tradition of Mokranjac's means and procedures, as well as the way of processing folklore music material. The harmonic language of the composer in songs is just a step forward in the contemporary space of folklore expression with unequivocal connection and growing out of Mokranjac's patterns coded in the Song-wreaths. According to Dejan Despić, folk melodies "with their tone (and especially important - diatonic), as well as scale-tonal features, ... conditioned - as, after all, other creators of national "schools" in the $19^{\text {th }}$ century - certain restrictions on the harmonic language" (Despić 1999, 151), which will obviously affect Konjović, as the immediate successor of Mokranjac and continuator of tradition. Namely, Despić's understanding that Mokranjac "established a specific norm of harmonization of our folklore", or that Stevan Hristić" set up some kind of harmonic system" (Despić 1999, 157), is obviously correct, since Konjović, processingthe song to a greater degree of chromatization with more bold harmonic steps up to a more modern approach - actually accepted and upgraded Mokranjac's "system" by a moderate evolution of harmonic means controlled by stimulating folklore impulses and a tendency to preserve the folk tone.

Finally, starting from the filigree text processing in the demanding creative process, Konjović in his most famous musical-scenic creation modeled not only Koštana's songs to the remarkable brilliance, but also the songs of other protagonists, achieving a powerful dramaturgic effect through the balance of words and tone, and through the balance of dramatic and expressive musical aspect. The vertical dimension of the analyzed songs shows the artful diffraction of the tonal and modal space with specific folklore scales and formulas, which, with the richness and diversity of the chord relationships, points to the individual harmonic system and the musical thinking of Petar Konjović as a unique representative of the national orientation in Serbian music of the modern epoch.

\section{REFERENCES}

Andreis, J., Cvetko, D., Đurić-Klajn, S., (1962), Historijski razvoj muzičke kulture u Jugoslaviji. Školska knjiga, Zagreb.

Ilić, I., (2007), Fatalna žena. Reprezentacije roda na operskoj sceni, Fakultet muzičke umetnosti, Beograd.

Milojević, M., (1933), "Tri opere Petra Konjovića". U: Muzičke studije i članci: druga knjiga. Izdavačka knjižnica Gece Kona, Beograd: pp. 56-78.

Mosusova, N., (1971), "O Koštani Petra Konjovića", U: Tuksar, S. (urednik). Arti musices 2. Muzikološki zavod Muzičke akademije, Zagreb: pp.153-166.

Peričić, V., (1968), Razvoj tonalnog sistema, Umetnička akademija u Beogradu, Beograd.

Stamatović, I., (2002), "Dramaturška funkcija Koštaninog pevanja u operi Petra Konjovića", TkH 3. Časopis za teoriju izvođačkih umetnosti. TkH centar za teoriju izvođačkih umetnosti, pp.78-87.

Tomašević, K., (2004), Srpska muzika na raskršću Istoka i Zapada. O dijalogu tradicionalnog i modernog u srpskoj muzici između dva svetska rata, Doktorska disertacija, Beograd, Fakultet muzičke umetnosti. 
Tomašević, K., (2014), "Imagining the Homeland: The Shifting Borders of Petar Konjović's Yugoslavisms", In: Melita M. and Samson J. (ed.), Serbian Music: Yugoslav Contexts. Institute of Musicology SASA, Belgrade.

Буловић, Б., (1998), „Хармонски језик и фолклор у делу Петра Коњовића”, Зборник Матице српске за сценске уметности и музику, Нови Сад, Марица Српска, стр. 22-23, 145-162.

Вујаклија, М., (1980), Лексикон страних речи и израза, Београд: Просвета.

Деспић, Д., (1999), „Хармонски језик и хорска фактура у Мокрањчевим делима”, У: Стеван Стојановић Мокрањаи: живот и дело, Завод за уџбенике и наставна средства, Београд.

Фогель, Я., (1982), Леош Яначек, Музыка, Москва.

Гуляницкая, Н. С., (1984), Введение в современную гармонию, Музыка, Москва.

Земцовский, И. И., (1971), „Фольклор и композитор”, У: Музыка и современность. Вып. 7, стр. 211-220.

Коњовић, П., (1947), Къига о музици: српској и славенској, Матица српска, Нови Сад.

Ярустовский, Б. М., (1953), „Нови Сад, Образ положительного героя в советской опере”, У: Советская опера: сборник критических статей, Музыкальное издательство, Москва.

\section{HARMONSKO-DRAMATURŠKE KARAKTERISTIKE PESAMA HADŽI-TOME I ALILA U MUZIČKOJ DRAMI KOŠTANA PETRA KONJOVIĆA}

Istraživanje u prethodnim radovima harmonskog izraza i dramaturške uloge Koštaninih, kao $i$ horskih pesama u muzičkoj drami Petra Konjovića, odredilo je analitički fokus na harmonski stil $i$ stvaralački izraz kompozitora u pesmama ostalih protagonista. Polazeći od hipoteze da je harmonska komponenta jedan od najvažnijih elemenata Konjovićevog stvaralačkog izraza, učinilo nam se neophodnim da precizno utvrdimo sredstva i vokabular, odnosno harmonski potencijal operske poetike kompozitora u pesmama Hadži-Tome i Alila. Kao poseban istraživački izazov pokazala se njihova muzičko-dramaturška funkcija i kompozitorov odnos prema folkloru koji vodi ka individualnom Konjovićevom pristupu harmonizaciji narodne pesme, sagledan jednim delom sa aspekta Konjovićevog odnosa prema Mokranjcu. Vertikalna dimenzija analiziranih pesama beleži vešto prelamanje tonalog $i$ modalnog prostora sa specifičnim folklornim lestvicama i formulama, što uz bogatstvo i raznovrsnost akordskih odnosa ukazuje na individualni harmonski sistem i muzičko mišljenje Petra Konjovića kao samosvojnog predstavnika srpskog nacionalnog identiteta i orijentacije.

Ključne reči: Konjović, Koštana, dramaturgija, folklor, pesma, tonalitet, akord. 